\title{
Research on the Individual Income Tax-Deferred Commercial Endowment Insurance from the Perspective of Fairness
}

\author{
Tingshan Song, ${ }^{1}$ Huilin Zhu, ${ }^{2}$ Jinrui Xiao, ${ }^{3}$ Zhi Qiao, ${ }^{4}$ Wenguang Yu $\mathbb{D},{ }^{4}$ and Xinliang Yu ${ }^{4}$ \\ ${ }^{1}$ School of Economics and Management, Qilu Normal University, Jinan 250200, China \\ ${ }^{2}$ School of Insurance, Southwestern University of Finance and Economics, Chengdu, Sichuan 611130, China \\ ${ }^{3}$ School of Finance, Zhongnan University of Economics and Law, Wuhan, Hubei 430073, China \\ ${ }^{4}$ School of Insurance, Shandong University of Finance and Economics, Jinan, Shandong 250014, China \\ Correspondence should be addressed to Wenguang Yu; yuwg@sdufe.edu.cn
}

Received 7 August 2021; Revised 10 December 2021; Accepted 13 December 2021; Published 7 January 2022

Academic Editor: Baogui Xin

Copyright $\odot 2022$ Tingshan Song et al. This is an open access article distributed under the Creative Commons Attribution License, which permits unrestricted use, distribution, and reproduction in any medium, provided the original work is properly cited.

\begin{abstract}
In order to alleviate the pressure of the basic endowment insurance system, China has implemented the policy of individual income tax-deferred commercial endowment insurance (IITDCEI) and actively explored the development path of individual supplementary endowment insurance. At present, the same tax rules are adopted for different income groups. Considering that people's income gap is large, different income groups enjoy different degrees of tax preference under this policy, which may cause social injustice and increase the gap between the rich and the poor. Based on this, we propose a new optimization scheme by adjusting the tax rate and the maximum premium limit of the insurance amount so as to coordinate the interests of low-, medium, and high-income subjects and balance the degree of tax preference among the three subjects. At the same time, we also change the two parameters of the predetermined interest rate and retirement age, and compare the changes of the tax preference under the old and new schemes, and provide corresponding countermeasures for the implementation of the IITDCEI policy.
\end{abstract}

\section{Introduction}

There are three pillars in China's endowment insurance system: the first pillar is social basic endowment insurance, the second is the supplementary endowment insurance of enterprises, including enterprise pension and occupational pension, and the third is individual supplementary endowment insurance. At present, China's endowment insurance system mainly relies on the first pillar. With the deepening of aging in China, the situation of China's basic endowment insurance system is grim, and problems such as the fund gap continue to emerge. How to alleviate the pressure of the first pillar has become an urgent problem to be solved in China. In addition, the development of China's three pillars is unbalanced, the second pillar is small in scale and coverage, the third pillar is slow in development, and the development of the second and the third pillars still have a large room for improvement.

In 2018, the Ministry of Finance and other five ministries and commissions jointly issued the notice on carrying out the pilot of IITDCEI, which clearly put forward the pilot of implementing the individual income tax-deferred policy. "Individual income tax deferral" is to change the original Tax Exempting Exempting (TEE) mode into EET mode, reduce the tax amount during the payment period, so as to encourage people to buy supplementary endowment insurance. In TEE mode, the policyholder pays taxes during the payment period and is duty-free during the investment period and collection period. In Exempting Exempting Tex (EET) mode, the policyholder's premium during the payment period is allowed to be deducted before tax, and is duty-free during the investment period, and pays tax according to a certain proportion at the time of collection. Due to the influence of progressive tax rate system and time value, different income groups enjoy different tax preferences under this policy, which may cause social injustice and increase the gap between the rich and the poor. Therefore, it has profound theoretical value and practical significance to find a suitable optimization scheme to reduce the unfairness of policy. 
IITDCEI is a kind of innovative endowment insurance product based on the theory of tax expenditure. Its main function is to provide tax preference for policyholders, and at the same time, it can bring additional benefits for savings, consumption, and investment. In recent years, IITDCEI has become a hot topic for scholars at home and abroad. At present, the research on the IITDCEI by foreign scholars is relatively mature. Creedy and Guest [1] took Australia as an example to analyze the impact of tax changes on consumption, labor supply, savings, and social welfare under different tax patterns. Poterba [2] pointed out that because retirement savings would be affected by tax rules and other factors, different income groups, especially high-income groups, would adopt pension plans with tax rules to increase savings. Beshears et al. [3] studied whether pretax contributions and posttax contributions of 401(k) plans can affect individual participation rate. Karamcheva and Sanzenbacher [4] showed that low, middle, and high-income groups have different enthusiasm for deferred endowment insurance, and high-income groups have the highest enthusiasm for insurance. Antón [5] used tax statistics to explore the distribution impact of tax deductions on private pensions in Spain in 2002. Some scholars have analyzed the feasibility of the existing tax deferral scheme. Collins [6] found that although supporting pension savings by providing tax deductions has become an important part of the welfare state, the relevant tax support is skewed in terms of gender, the gender income gap continues until retirement, and there is a discontinuity between longevity expectation and the tax policy support provided by pension. Joulfaian and Richardson [7] believed that due to different discount periods and tax rates, the implementation of individual taxdeferred policy would bring loss to the net tax income and increase the tax pressure on the government. Andersen [8] believed that middle and high-income groups can further increase their savings rate through tax preference.

Most Chinese scholars' studies on IITDCEI focus on three aspects: policy impact, implementation feasibility, and social equity. In the process of implementing individual income tax-deferred endowment insurance, it is necessary to coordinate the relationship between various stakeholders and how to take into account the interests of all parties and solve the fairness problem to the greatest extent. Many scholars have carried out research on it. Peng et al. [9] pointed out that due to the social gap between different income groups, there were certain social inequities in adopting IITDCEI and proposed the solution of giving subsidies to low-income groups and encouraging them to participate in individual endowment insurance plan. Zhu and Tao [10] pointed out that there were still tax inequities between different income classes and different types of income in the existing system from the two dimensions of horizontal fairness and vertical fairness. They suggested that the personal income tax system should treat labor income and capital income equally to reflect horizontal equity and proposed that the classified collection system should be gradually changed into a comprehensive tax system to give consideration to horizontal fairness and vertical fairness, and strengthen the tax collection and management of high- income groups, so as to strengthen vertical fairness. Huang and Wang [11], Ji et al. [12, 13] found that after the implementation of the deferred income tax policy, there were certain differences in the degree of reduction in the level of security for employees of different genders, different income levels, and different payment ratios, and whether to buy relevant products will also have different effects. Yuan and Guo [14] believed that the system should be optimized from the following aspects: the establishment of a tax deferral model combining EET and TEE, the establishment of different tax deferral limits for different groups, the payment subsidies for low-income people and women and other vulnerable groups, and the expansion of the function of personal pension savings account. Fan et al. [15] put forward the scheme of grading the tax rate of IITDCEI in view of the "one size fits all" mode adopted by the current tax-deferred commercial endowment insurance in China so as to make more people get tax preference.

The domestic research on the policy implications and implementation feasibility of IITDCEI is relatively perfect. However, the research on the fairness of different income groups mainly focuses on qualitative aspects, while the research on quantitative aspects is less. Therefore, in view of the fairness problems existing in different income groups, that is, the different degree of tax preference, this paper puts forward the idea of adjusting the tax rate and the maximum premium limit of the insurance amount by category, and provides some suggestions for the implementation of the IITDCEI.

The remainder of this paper is organized as follows. In Section 2, we provide the construction and numerical calculation of the model of IITDCEI. In Section 3, the Optimization of the scheme of IITDCEI for low and high-income groups is investigated. In Section 4, we present an analysis of tax preference under different factors based on the new and old schemes. Finally, conclusions and suggestions are given in Section 5.

\section{Model Construction and Numerical Calculation}

This paper calculates the individual's tax payment under the TEE and EET modes; that is, the wage income after deducting the five social insurances and housing fund and the threshold amount under the TEE mode is calculated according to the progressive tax rate system; the wage income after deducting the five social insurances and housing fund, threshold amount and the insurance amount under the EET mode is calculated according to the progressive tax rate system, and the pension received during the collection period is calculated according to the proportion stipulated in the policy. Considering the time value of money, this paper takes the retirement age of the policyholder as the time point, calculates the total amount under the two modes, respectively. The total amount of the previous period is accumulated to this time point, and the amount of tax paid in the later payment is discounted to this time point, and the comparison is made. At the same time, this paper believes that whether the policyholder benefits fairly under EET 
mode is measured by the degree of tax preference enjoyed by the policyholder. This paper will use the tax-saving index to measure the degree of tax preference. That is, the tax-saving effect of each policyholder under different income levels is compared by dividing the tax difference under TEE mode and EET mode by the total amount under TEE mode.

2.1. Parameter Assumption and Value. The parameters in this paper are mainly selected according to the current national policies and historical data. At the same time, these parameters are only to more intuitively reflect the trend, and the adjustment of individual parameters does not affect the main conclusions.

(1) Retirement age: taking into account the extended retirement policy, it is assumed that both men and women will retire at the age of 60 .

(2) Insurance payment and pension payment: this paper assumes that the insured pays the premium at the beginning of the year from the first year of work to the last year of work and assumes that the measuring subjects all survive until retirement. When you retire at the age of 60 , you can get a pension according to the agreement. You can get the same amount of pension at the beginning of each year and get it for life.

(3) Wage level: $W_{t}$ is the annual wage of the policyholder at the age of $(t+x),(t=0,1,2 \ldots 59-x)$. In 2018 , the average social annual wage of urban workers in China was 82461 yuan, and the average monthly wage was 6871.75 yuan. Referring to the social average wage of urban workers in China, this paper divides the income groups into three levels: the low-income group is defined as the group receiving 0.75 times or less of the social average wage, the middle-income group is defined as the group receiving 0.75 to 1.5 times of the social average wage, and the high-income group is defined as the group receiving 1.5 times or more of the social average wage.

(4) Predetermined interest rate $i$ : based on the notice of the China Insurance Regulatory Commission on the reform of ordinary life insurance rate policy and the inflation rate in recent years, this paper sets the predetermined interest rate as $3.5 \%$.

(5) Wage growth rate $g$ : this paper assumes that China's average wage growth is synchronized with the economic growth, and that China's economy maintains a growth rate of $5 \%$, that is, $g=5 \%$.

(6) Tax rate table: the seven level excess progressive personal income tax rate table is adopted, and the personal income tax $=($ wages - five social insurances and housing fund -threshold amount - additional special deduction) $\times$ tax rate- quick calculation deduction. This paper does not consider the additional special deduction and sets the total proportion of five social insurances and housing funds as $19 \%$, that is, $\gamma=19 \% \cdot \beta_{j}(j=1,2,3,4,5,6,7)$ is the corresponding withholding tax under each level, $S_{j}$ is the corresponding quick calculation deduction under each level. The threshold is set to 60000 , i.e., $F=60000$.

(7) Tax rate of insurance payment $\alpha$ : according to the current regulation, when an individual receives the IITDCEI fund, $25 \%$ of it will be exempted from tax, and $75 \%$ of it will pay personal income tax at the rate of $10 \%$, which is equivalent to $\alpha=7.5 \%$.

(8) The highest survival age is $\omega$, and the initial working age was $x$. It is assumed that the maximum death age of the insured is 100 years old, and this paper assumes that employees begin to work at the age of 26.

(9) Survival probability ${ }_{t} p_{x}$ : the calculation of survival probability is based on the life experience table of the Chinese life insurance industry (2010-2013).

(10) Paying the premium $P_{t}$ : suppose that the monthly premium of commercial endowment insurance is $6 \%$ of the wage, and the maximum monthly premium is 1000 yuan.

(11) Insurance pay-offs fund $G$.

\subsection{Tax-Saving Calculation of IITDCEI}

2.2.1. Model Construction of Tax-Saving Rate. This paper uses the current IITDCEI policy in the pilot area, calculates the tax difference between TEE mode and EET mode, and compares the tax-saving effect of different income groups.

The annual premium paid by individuals is as follows:

$$
P_{t}=\min \left\{6 \% \times W_{t}, 12000\right\} \text {. }
$$

The tax paid under tee mode is as follows:

$T_{\mathrm{TEE}}=\sum_{t=0}^{59-x}\left[\left(W_{t}-\gamma W_{t}-F\right) \times \beta_{j}-S_{j}\right] \times(1+i)^{60-x-t}$.

Under EET mode, the amount of tax paid during the payment period is as follows:

$T_{1}=\sum_{t=0}^{59-x}\left[\left(W_{t}-\gamma W_{t}-F-P_{t}\right) \times \beta_{j}-S_{j}\right] \times(1+i)^{60-x-t}$.

Assuming that the insurance company does not consider the management cost, according to the principle of actuarial equilibrium equivalence, the accumulated value of the premium paid in the early stage is equal to the actuarial present value received in the later stage, that is,

$$
\sum_{t=0}^{59-x} P_{t} \times(1+i)^{60-x-t}=\sum_{t=0}^{\omega-60} G \times\left(\frac{1}{1+i}\right)^{t} \times{ }_{t} P_{x} .
$$

Under EET mode, the later actuarial present value can be converted into the accumulated value of the previous 
payment multiplied by the corresponding tax rate, so the tax paid under EET mode is as follows:

$$
T_{2}=\sum_{t=0}^{59-x} P_{t} \times \alpha \times(1+i)^{60-x-t} .
$$

The total amount of tax paid under EET mode is as follows:

$$
\begin{aligned}
T_{\mathrm{EET}}= & T_{1}+T_{2} \\
= & \sum_{t=0}^{59-x}\left[\left(W_{t}-\gamma W_{t}-F-P_{t}\right) \times \beta_{j}-S_{j}\right] \times(1+i)^{60-x-t} \\
& +\sum_{t=0}^{59-x} P_{t} \times \alpha \times(1+i)^{60-x-t} .
\end{aligned}
$$
follows:

The difference between TEE mode and EET mode is as

$$
\begin{aligned}
\Delta T= & T_{\mathrm{TEE}}-T_{\mathrm{EET}} \\
= & \sum_{t=0}^{59-x}\left[\left(W_{t}-\gamma W_{t}-F\right) \times \beta_{j}-S_{j}\right] \times(1+i)^{60-x-t} \\
& -\sum_{t=0}^{59-x}\left[\left(W_{t}-\gamma W_{t}-F-P_{t}\right) \times \beta_{j}-S_{j}\right] \times(1+i)^{60-x-t} \\
& -\sum_{t=0}^{59-x} P_{t} \times \alpha \times(1+i)^{60-x-t} .
\end{aligned}
$$

The tax-saving effect of each policyholder under different income levels is measured by dividing the difference of tax payment under TEE mode and EET mode by the total amount under TEE mode; that is, the tax-saving rate is as follows:

$$
\theta=\frac{\Delta T}{T_{\mathrm{TEE}}}
$$

2.2.2. Calculation of the Model. We take three groups of monthly wage values from each of the three income classes for calculation, and the results are shown in Table 1 .

It can be seen from Table 1 that the tax difference between TEE mode and EET mode increases with the increase of income level. For the group with an initial monthly income of 3000 yuan, the total amount of tax saving is -11161.69 yuan, which indicates that the current EET mode has no tax-saving effect on the group. The main reason is that the group's initial monthly income is low and does not meet the standard, so there is no need to pay tax under TEE mode, while in EET mode, the stage of insurance pay-offs fund increases the tax expenditure of this group. For the group with an initial monthly income of 5000 yuan, the total amount of tax saving is positive, but the tax rate is low, and the effect of tax saving is negligible. In comparison, the total tax-saving amount of the group with an initial monthly income of 10000 yuan is 50176.91 yuan, and the tax-saving rate is the highest. It can be seen that the group has the best tax-saving effect and the greatest benefit. With the increase of initial monthly income, the setting of the maximum premium limit leads to the decrease of the taxsaving rate of higher-income groups. It can be concluded that the middle-income group has the best tax-saving effect, and the low-income group has the worst tax-saving effect. The taxsaving rate of the group with an initial monthly income of 10000 yuan is the highest. Although the high-income group is relatively better at tax saving, there is a tax saving limit. Under the EET model, there is a big difference in the tax-saving effect among the three groups. Compared with the middle-income group, the tax-saving effect of the low-income group and the high-income group is weaker, and there is a big gap in the benefit degree of the three groups. That is, there is a certain unfairness in adopting the EET model. The tax savings under different wages are intuitively reflected in Figure 1.

\section{Optimization of the Scheme of IITDCEI for Low- and High-Income Groups}

In order to prevent the Matthew effect, it is necessary to set premium limits for high-income groups. Since the tax savings in the pilot area is the maximum of 1000 yuan and 6\% of wages, the policy has little impact on people whose income is higher than a certain level. For the high-income group whose initial monthly income is more than 20000 yuan, the limited tax preference has little effect on it. Based on this, this paper only considers the high-income group whose initial monthly income is less than 20000 yuan. Under the current policy, when the tax-saving rate and tax-saving amount are zero, the critical value of the initial monthly income can be calculated as 4919.55 yuan. That is, the group whose initial monthly income is lower than this value will not be able to enjoy the tax preference if they purchase the IITDCEI. Therefore, this paper temporarily divides the low-income group into two parts: below 4919.55 yuan and between 4919.55 and 5153.81 yuan. The redivision of income groups according to the initial monthly income is shown in Table 2.

In order to make the tax-saving preferential effect of each income group relatively consistent and give the three groups roughly the same incentive degree to buy the individual IITDCEI, this paper uses the tax-saving rate to measure the tax-saving effect among the three groups and takes the taxsaving rate of the middle-income group [4\%, 5\%] as the standard. By taking different measures for the low-income group and the high-income group, the tax-saving rate of each income group can be stabilized in the same range so as to realize the relative fairness of the policy.

Next, we will change the tax rate of the receiving stage to analyze the impact of the change on the low-income group and change the maximum limit of premium to analyze the impact on the high-income group. On this basis, we will optimize the existing scheme to make the benefits of low, middle, and high-income groups relatively fair in the existing IITDCEI. The specific practice is to adjust the tax rate of the insurance amount of the low-income group and adjust the maximum premium limit of the high-income group on the basis of the original policy. Considering that the tax-saving effect of the low-income group is very little, the insurance amount tax rate $\alpha$ of the low-income group is reset here, taking $\alpha$ as $2 \%, 2.5 \%, 3 \%, 3.5 \%, 4 \%, 4.5 \%, 5 \%$, and 
TABLe 1: Tax difference and tax-saving rate under TEE mode and EET mode under different income levels.

\begin{tabular}{|c|c|c|c|c|}
\hline Initial monthly salary (yuan) & $T_{\mathrm{TEE}}$ & $T_{\text {EET }}$ & $\Delta T$ & $\theta$ \\
\hline 3000 & 44502.76 & 55664.45 & -11161.69 & $-25.08 \%$ \\
\hline 4000 & 112483.16 & 120309.93 & -7826.78 & $-6.96 \%$ \\
\hline 5000 & 210401.07 & 209759.19 & 641.88 & $0.31 \%$ \\
\hline 8000 & 684980.53 & 654980.12 & 30000.41 & $4.38 \%$ \\
\hline 9000 & 889574.31 & 849856.97 & 39717.35 & $4.46 \%$ \\
\hline 10000 & 1114440.99 & 1064264.07 & 50176.91 & $4.50 \%$ \\
\hline 13000 & 1893738.23 & 1818501.98 & 75236.25 & $3.97 \%$ \\
\hline 14000 & 2180743.49 & 2099000.97 & 81742.52 & $3.75 \%$ \\
\hline 15000 & 2480019.06 & 2390399.91 & 89619.15 & $3.61 \%$ \\
\hline
\end{tabular}

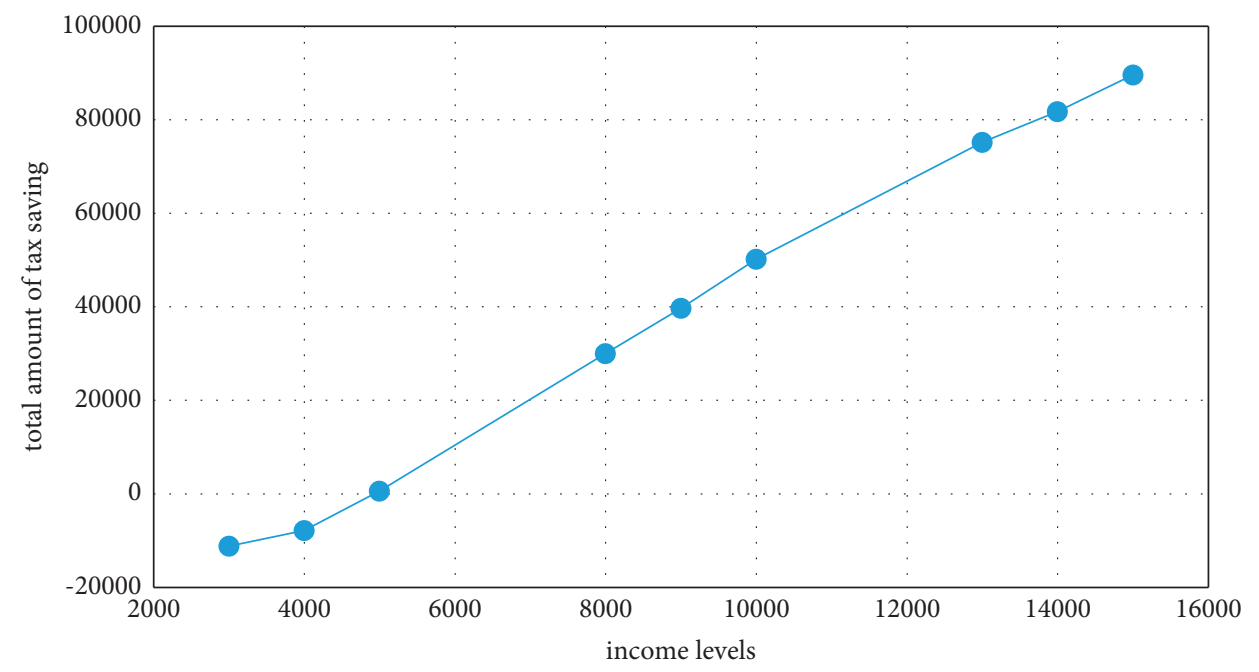

FIgURE 1: The total amount of tax savings under different income levels.

Table 2: Division table of income groups.

\begin{tabular}{lcc}
\hline Classification of income groups & Initial monthly income (yuan) & Note \\
\hline Low-income group & Below 4919.55 & Groups to be measured \\
Middle-income group & Between 4919.55 and 5153.81 & \\
High-income group & Between 5153.81 and 10307.63 & No considering \\
\hline
\end{tabular}

$5.5 \%$, respectively, to calculate the groups with the initial monthly income of 3000,4000 , and 5000 yuan. The premium paid by the high-income group is $P_{\mathrm{t}}=\min \left\{6 \% \times W_{t}, t \delta\right\}$, where the maximum premium limit is $\delta$. Taking $\delta$ as 1000 , $1100,1200,1300,1400$, and 1500 , respectively, this paper calculates the groups with an initial monthly income of 13000,14000 , and 15000 yuan.

\subsection{Analysis and Calculation on Tax Saving of IITDCEI for} Low-Income Group. The calculation results of tax payment difference and tax-saving rate under TEE mode and EET mode are shown in Table 3 . With the increase of the tax rate of insurance amount, the total tax-saving amount and tax rate decrease continuously, and the two have a reverse change relationship. It can also be seen from Figure 2 that the tax-saving rate of the group with an initial monthly income of 3000 yuan is the most sensitive to the tax rate of insurance amount. With the increase of monthly income, the sensitivity decreases. If the high-income group adopts the method of adjusting the tax rate of insurance amount, the effect is not as obvious as the low-income group. Therefore, this paper adopts this method for low-income groups, and the results are as follows: When the tax rate of insurance amount for the group with an initial monthly income of 3000 yuan is between $[3 \%, 3.5 \%]$, the tax-saving rate is stable in the range of $[2.15 \%, 5.55 \%]$. At this time, the tax-saving effect of the group and the middle-income group is roughly the same. However, with the increase of the tax rate of insurance payment, when the tax rate of insurance payment is within the range of $[4 \%, 5 \%]$, the tax-saving rate will continue to decrease or even become negative. For the group with a negative tax rate, if the insurance amount of the group is taxed, it is impossible for the group to achieve the same 
TABle 3: Tax difference and tax-saving rate of the low-income group under different insurance amount tax rates.

\begin{tabular}{|c|c|c|c|c|c|}
\hline$\alpha$ & Initial monthly income (yuan) & $T_{\mathrm{TEE}}$ & $T_{\mathrm{EET}}$ & $\Delta T$ & $\theta$ \\
\hline \multirow{3}{*}{0.020} & 3000 & 44502.760 & 39003.741 & 5499.019 & $12.36 \%$ \\
\hline & 4000 & 112483.159 & 98427.762 & 14055.397 & $12.50 \%$ \\
\hline & 5000 & 210401.069 & 183626.260 & 26774.809 & $12.73 \%$ \\
\hline \multirow{3}{*}{0.025} & 3000 & 44502.760 & 40518.350 & 3984.410 & $8.95 \%$ \\
\hline & 4000 & 112483.159 & 100417.050 & 12066.109 & $10.73 \%$ \\
\hline & 5000 & 210401.069 & 186001.980 & 24399.088 & $11.60 \%$ \\
\hline \multirow{3}{*}{0.030} & 3000 & 44502.760 & 42032.960 & 2469.800 & $5.55 \%$ \\
\hline & 4000 & 112483.159 & 102406.338 & 10076.821 & $8.96 \%$ \\
\hline & 5000 & 210401.069 & 188377.701 & 22023.367 & $10.47 \%$ \\
\hline \multirow{3}{*}{0.035} & 3000 & 44502.760 & 43547.570 & 955.190 & $2.15 \%$ \\
\hline & 4000 & 112483.159 & 104395.627 & 8087.532 & $7.19 \%$ \\
\hline & 5000 & 210401.069 & 190753.422 & 19647.647 & $9.34 \%$ \\
\hline \multirow{3}{*}{0.040} & 3000 & 44502.760 & 45062.180 & -559.420 & $-1.26 \%$ \\
\hline & 4000 & 112483.159 & 106384.915 & 6098.244 & $5.42 \%$ \\
\hline & 5000 & 210401.069 & 193129.143 & 17271.926 & $8.21 \%$ \\
\hline \multirow{3}{*}{0.045} & 3000 & 44502.760 & 46576.790 & -2074.030 & $-4.66 \%$ \\
\hline & 4000 & 112483.159 & 108374.204 & 4108.955 & $3.65 \%$ \\
\hline & 5000 & 210401.069 & 195504.864 & 14896.205 & $7.08 \%$ \\
\hline \multirow{3}{*}{0.050} & 3000 & 44502.760 & 48091.399 & -3588.639 & $-8.06 \%$ \\
\hline & 4000 & 112483.159 & 110363.492 & 2119.667 & $1.88 \%$ \\
\hline & 5000 & 210401.069 & 197880.584 & 12520.484 & $5.95 \%$ \\
\hline \multirow{3}{*}{0.055} & 3000 & 44502.760 & 49606.009 & -5103.249 & $-11.47 \%$ \\
\hline & 4000 & 112483.159 & 112352.781 & 130.378 & $0.12 \%$ \\
\hline & 5000 & 210401.069 & 200256.305 & 10144.764 & $4.82 \%$ \\
\hline
\end{tabular}

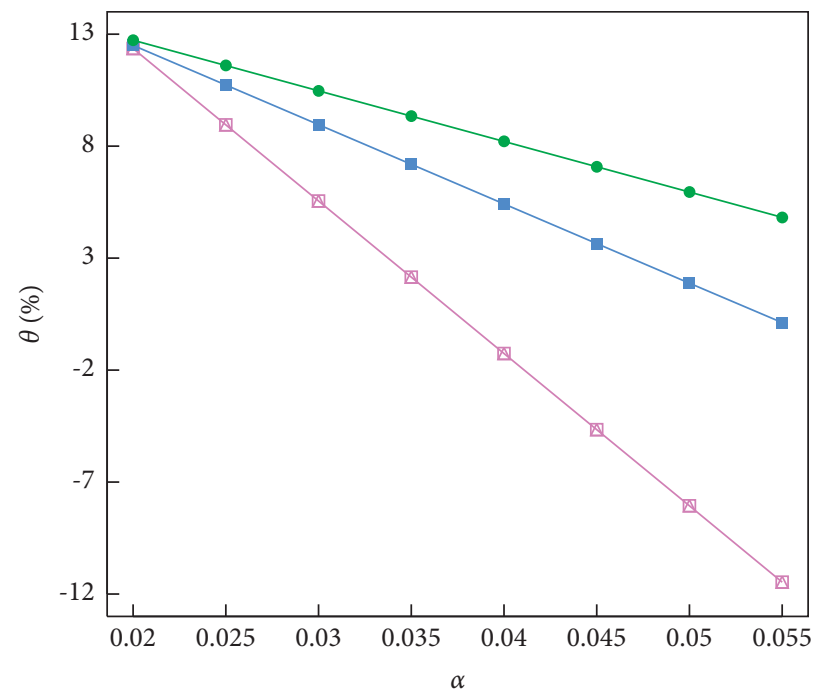

initial monthly income (yuan)

$$
\begin{aligned}
& \triangle \quad 3000 \\
& -\quad 4000 \\
& \longrightarrow 5000
\end{aligned}
$$

FIGURE 2: Tax-saving rate under the tax rate of different insurance amounts.

degree of tax preference as the middle-income group, which means that the tax payment of the group in the receiving stage is obviously unfair. The tax-saving effect of the group with an initial monthly income of 4000 yuan and insurance amount tax rate in the range of $[4 \%, 4.5 \%]$ is similar to the group with an initial monthly income of 5000 yuan and insurance amount tax rate in the range of $[5 \%, 5.5 \%]$, and the tax-saving rate is stable in the range of $[4 \%, 5 \%]$.

After adjusting the tax rate of the insurance amount in the receiving stage, the optimization scheme is shown in Table 4. As the group whose initial monthly income is less than 3000 yuan can not enjoy the tax preference, it is suggested that the 
TABLE 4: Tax rate adjustment table for low-income groups to receive insurance benefits.

\begin{tabular}{lr}
\hline Initial monthly income (yuan) & Tax rate of insurance payment \\
\hline Below 3000 & $0 \%$ \\
Between 3000 and 4000 & {$[3 \%, 3.5 \%]$} \\
Between 4000 and 5000 & {$[4 \%, 4.5 \%]$} \\
Between 5000 and 5153.81 & {$[5 \%, 5.5 \%]$}
\end{tabular}

state should not levy the tax on insurance payment; that is, set the tax rate at $0 \%$ to encourage the group to buy insurance. Compared with the current scheme, it is feasible to adjust the tax rate of the insurance amount in the receiving stage. On the one hand, it improves the tax-saving rate of low-income groups, and on the other hand, it enables some low-income groups whose initial monthly income is less than 4919.55 yuan to enjoy tax preference.

\subsection{Analysis and Calculation of Tax Saving of IITDCEI for} High-Income Group. The calculation results of tax payment difference $\Delta T$ and tax-saving rate $\theta$ under TEE mode and EET mode are shown in Table 5 . The groups with an initial monthly income of 13000 yuan, 14000 yuan, and 15000 yuan have almost the same sensitivity to the change of the maximum premium limit. With the increase of the maximum premium limit, the total amount of tax saving and tax-saving rate continues to increase, indicating that the method of adjusting the maximum premium limit can improve the degree of the tax preference for high-income groups. It can be seen from Table 5 that when the maximum premium limit is in the range of $[1150,1250]$, the tax-saving rate is stable in the range of $[4 \%$, $5 \%$ ], which is relatively consistent with the tax-saving effect of middle-income groups. The tax-saving rate under different insurance amount tax rates is intuitively reflected in Figure 3.

3.3. The Optimization Scheme of IITDCEI. According to the above calculation of tax saving for low-income and high-income groups, the new optimization scheme is obtained, as shown in Table 6 . Through the analysis and comparison of tax payment difference and tax-saving rate among different income groups, the low-income groups are divided into three parts, and the tax rate of the insurance amount in the receiving stage for the groups with an initial monthly income of $3000-4000$ yuan and $4000-5000$ yuan is set as [4\%, 4.5\%], [5\%, $5.5 \%]$, respectively. For the other group whose income is too low and the total amount of tax saving is negative, that is, the initial monthly income is less than 3000 yuan, no tax will be collected when receiving the insurance amount. At the same time, the payment limit for high-income groups was adjusted to the range of $[1150,1250]$. At this time, the tax-saving effect of the low-income group, high-income group, and middleincome group under the current regulation is roughly equal.

\section{An Analysis of Tax Preference under Different Factors Based on the New and Old Schemes}

Through the two factors of changing the tax rate of the insurance amount in the receiving stage and the maximum payment limit, we get a new scheme of IITDCEI. For the convenience of calculation, we select the group with an initial monthly income of 5000 yuan, the tax rate of insurance amount of $5.5 \%$ in the receiving stage and initial monthly income of 13000 yuan, and a maximum payment limit of 1200 yuan/month. Change the predetermined interest rate and retirement age, and compare and analyze the tax preference of IITDCEI under the new and old schemes. Change the two parameters of the predetermined interest rate and the retirement age, compare and analyze the tax preference degree for the policyholder to participate in IITDCEI under the new and old schemes.

4.1. Analysis of Changes in Predetermined Interest Rates. According to the formula, the change of the predetermined interest rate will cause the change of the tax preference difference. Assuming the group with an initial monthly income of 5000 yuan, the tax rate of insurance amount in the receiving stage is $5.5 \%$ and $7.5 \%$, and the group with an initial monthly income of 13000 yuan, the maximum payment limit is 1200 yuan/month and 1,000 yuan/month, calculate the payment difference when the predetermined interest rate is $2 \%, 2.5 \%, 3 \%, 3.5 \%, 4 \%, 4.5 \%, 5 \%$, respectively.

As shown in Figure 4, with the increase of the predetermined interest rate, the difference of tax preference for low-income groups gradually decreases, while that for highincome groups gradually increases. Moreover, the difference in tax payment for the two income groups under the new scheme is always greater than that of the current scheme, and the difference in tax payment gradually increases. The reason that the difference of tax payment between the two income groups changes in the opposite direction may be that the monthly income of the low-income group under TEE mode can not reach the threshold of individual income tax, and there is no need to pay tax in the payment stage. While in EET mode, the insurance amount in the receiving stage needs to be taxed according to a unified proportion. With the increase of the predetermined interest rate, according to the principle of actuarial equilibrium equivalence, the total accumulated premium, i.e., the insurance amount, increases continuously, and the base of tax payment increases, which eventually leads to the gradual decrease of the difference of tax preference for low-income groups. With the increase of predetermined interest rate, the accumulated value of tax preference difference is increasing, and the tax preference difference of high-income group is gradually increasing.

4.2. Analysis of the Change of Retirement Age. With the deepening of aging and the improvement of life expectancy, there is a certain practical basis for the implementation of 
TABLE 5: Tax difference and tax-saving rate of the high-income group under the maximum premium limit.

\begin{tabular}{|c|c|c|c|c|c|}
\hline$\delta$ & Initial monthly income (yuan) & $T_{\mathrm{TEE}}$ & $T_{\text {EET }}$ & $\Delta T$ & $\theta$ \\
\hline \multirow{3}{*}{1000} & 13000 & 1893738.232 & 1818501.983 & 75236.249 & $3.97 \%$ \\
\hline & 14000 & 2180743.489 & 2099000.972 & 81742.517 & $3.75 \%$ \\
\hline & 15000 & 2480019.063 & 2390399.913 & 89619.150 & $3.61 \%$ \\
\hline \multirow{3}{*}{1100} & 13000 & 1893738.232 & 1811845.276 & 81892.956 & $4.32 \%$ \\
\hline & 14000 & 2180743.489 & 2091449.602 & 89293.887 & $4.09 \%$ \\
\hline & 15000 & 2480019.063 & 2382186.439 & 97832.624 & $3.94 \%$ \\
\hline \multirow{3}{*}{1200} & 13000 & 1893738.232 & 1805359.289 & 88378.943 & $4.67 \%$ \\
\hline & 14000 & 2180743.489 & 2084046.691 & 96696.798 & $4.43 \%$ \\
\hline & 15000 & 2480019.063 & 2374175.955 & 105843.108 & $4.27 \%$ \\
\hline \multirow{3}{*}{1300} & 13000 & 1893738.232 & 1799011.246 & 94726.986 & $5.00 \%$ \\
\hline & 14000 & 2180743.489 & 2076769.464 & 103974.025 & $4.77 \%$ \\
\hline & 15000 & 2480019.063 & 2366340.555 & 113678.508 & $4.58 \%$ \\
\hline \multirow{3}{*}{1400} & 13000 & 1893738.232 & 1792820.512 & 100917.720 & $5.33 \%$ \\
\hline & 14000 & 2180743.489 & 2069699.726 & 111043.763 & $5.09 \%$ \\
\hline & 15000 & 2480019.063 & 2358625.425 & 121393.638 & $4.89 \%$ \\
\hline \multirow{3}{*}{1500} & 13000 & 1893738.232 & 1787059.778 & 106678.454 & $5.63 \%$ \\
\hline & 14000 & 2180743.489 & 2063075.546 & 117667.943 & $5.40 \%$ \\
\hline & 15000 & 2480019.063 & 2351389.528 & 128629.535 & $5.19 \%$ \\
\hline
\end{tabular}

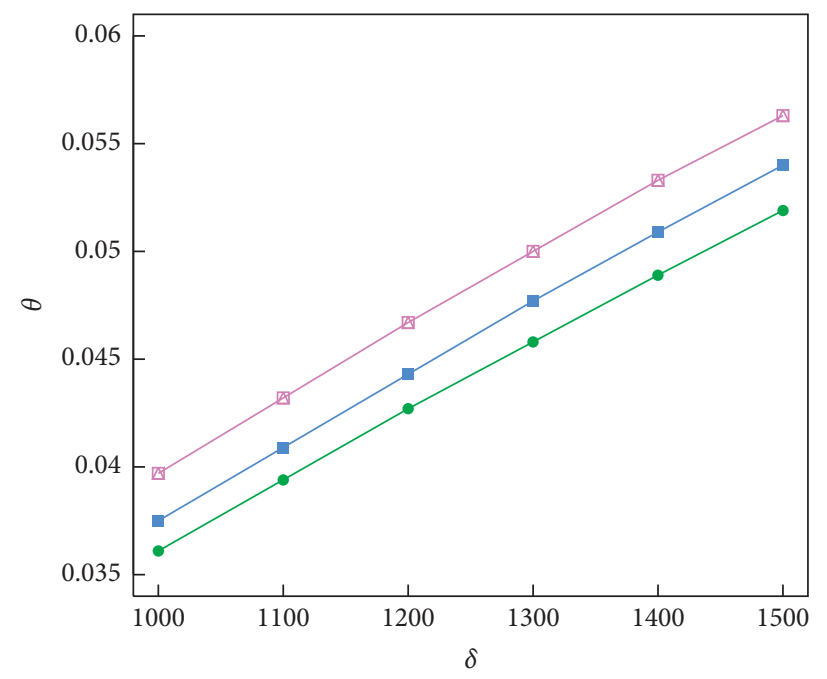

$$
\begin{aligned}
& \text { initial monthly income (yuan) } \\
& - \text { - } 13000 \\
& --14000 \\
& --15000
\end{aligned}
$$

Figure 3: Tax-saving rate under different insurance amount tax rates.

the policy of delaying retirement. Therefore, we consider the changes of tax payment differences for policyholders at different retirement ages.

Under the assumption that the retirement age of men and women is the same, this paper estimates the change of tax payment difference when the retirement age is extended to 68 .

The difference of actual tax payment between the group with an initial monthly income of 5000 yuan, a tax rate of insurance amount of $5.5 \%$ and $7.5 \%$ in the receiving stage and the group with an initial monthly income of 13000 yuan, maximum payment limit of 1200 yuan/ month and 1000 yuan/month is shown in Figure 4.

As shown in Figure 5, no matter how old the retirement age of the policyholder is, the difference of tax preference between the low-income group and the high-income group under the new scheme is always greater than that under the current scheme, and the difference of tax payment is gradually increasing. 
TABLE 6: The new and old optimization scheme of the IITDCEI.

\begin{tabular}{|c|c|c|c|c|}
\hline \multirow[b]{2}{*}{$\begin{array}{l}\text { Initial monthly } \\
\text { income (yuan) }\end{array}$} & \multicolumn{2}{|r|}{ Old scheme } & \multicolumn{2}{|c|}{ New scheme } \\
\hline & $\begin{array}{l}\text { Maximum payment } \\
\text { limit/month }\end{array}$ & $\begin{array}{l}\text { Tax rate of the insurance amount } \\
\text { in the receiving stage }\end{array}$ & $\begin{array}{l}\text { Maximum payment } \\
\text { limit/month }\end{array}$ & $\begin{array}{l}\text { Tax rate of the insurance amount } \\
\text { in the receiving stage }\end{array}$ \\
\hline Below 3000 & & & & $0 \%$ \\
\hline $\begin{array}{l}\text { Between } 3000 \text { and } \\
4000\end{array}$ & & & & {$[3 \%, 3.5 \%]$} \\
\hline $\begin{array}{l}\text { Between } 4000 \text { and } \\
5000\end{array}$ & & & 1000 & {$[4 \%, 4.5 \%]$} \\
\hline $\begin{array}{l}\text { Between } 5000 \text { and } \\
5153.81 \\
\text { Between } 5153.81 \\
\text { and } 10307.63\end{array}$ & 1000 & $7.50 \%$ & & {$[5 \%, 5.5 \%]$} \\
\hline $\begin{array}{l}\text { Between } 10307.63 \\
\text { and } 20000 \\
\text { Over } 20000\end{array}$ & & & 1200 & $7.50 \%$ \\
\hline
\end{tabular}
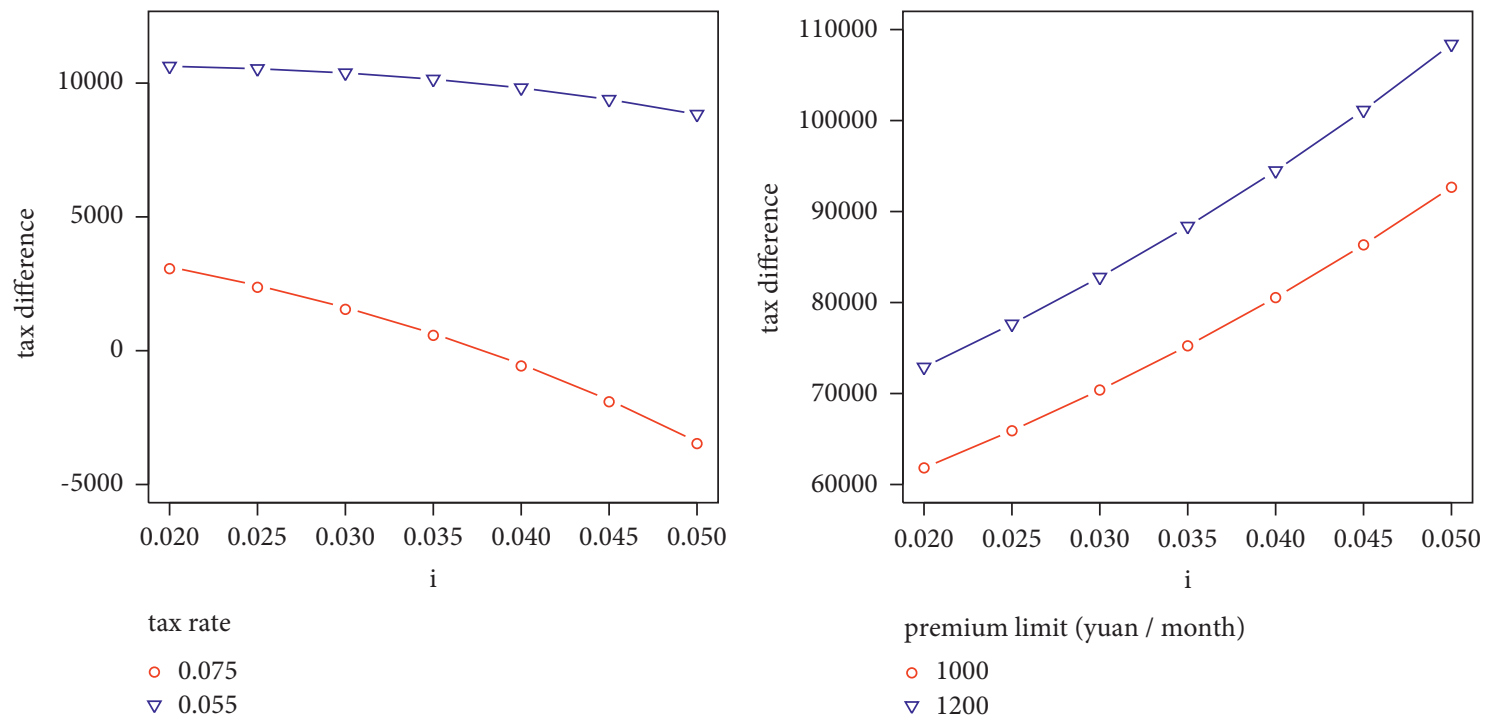

Figure 4: Tax difference under different predetermined interest rates.

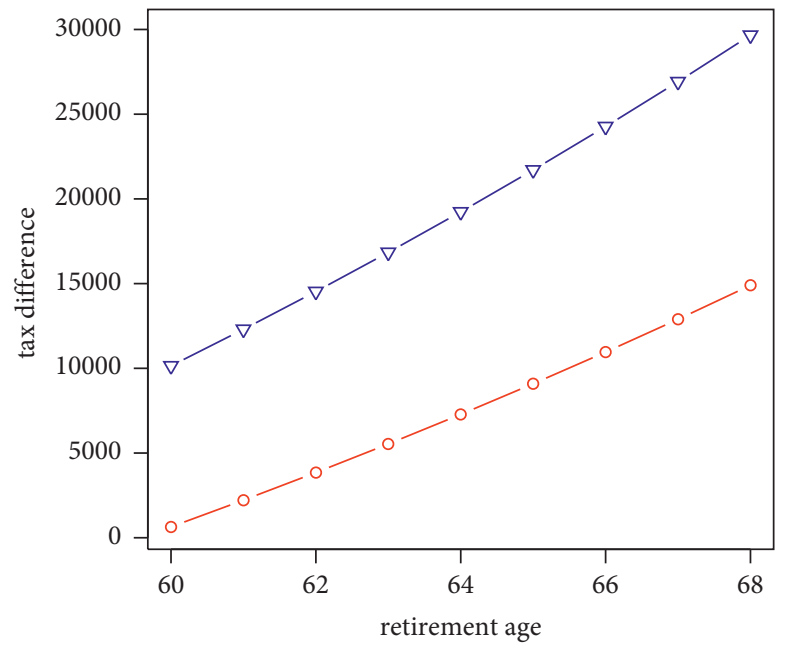

tax rate

$\circ 0.075$

$\nabla 0.055$

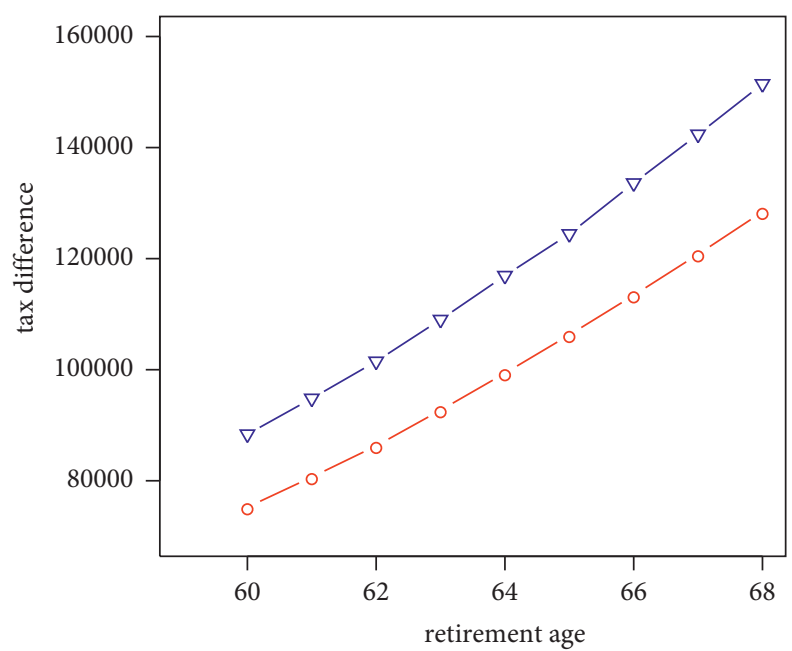

premium limit (yuan/month)

$$
\begin{array}{cr}
\circ & 1000 \\
\nabla & 1200
\end{array}
$$

Figure 5: Tax difference under different retirement ages. 


\section{Conclusions and Suggestions}

According to the calculation of tax savings of IITDCEI, the tax-saving effect of different income groups is quite different.

For the low-income group, due to the small base, the taxsaving effect of after the deferral of income tax is not obvious, even worse than the TEE model; for the high-income group, due to the limitation of the maximum premium limit, the tax-saving effect is gradually declining. It can be seen that under the current system of IITDCEI, the middle-income group benefits the most, while the low-income group and high-income group benefit less than the middle-income group. This policy is obviously unfair.

By calculating and analyzing the data of low-income groups and high-income groups after taking different measures, it can be seen that reducing the tax rate of the lowincome group to receive a premium can significantly improve the tax-saving effect. After increasing the maximum payment limit for the high-income group, the tax-saving effect has also been improved to a certain extent, that is, by adjusting the amount of tax saving by categories, the tax preference degree of all kinds of income groups is roughly the same, so as to reduce the unfairness.

Therefore, this paper suggests that in the implementation process of IITDCEI, the tax rate of insurance amount for low-income groups should be classified: for the groups with an initial monthly income of 3000-4000 yuan, 4000-5000 yuan, 5000-5153.81 yuan, the tax rate of the insurance amount in the receiving stage should be set in the range of [3\%, 3.5\%], [4\%, 4.5\%], [5\%, 5.5\%], and for the group with an initial monthly income of 3000 yuan or less, the tax rate is set at $0 \%$. The maximum premium limit for the high-income group is set between [1150, 1250], and for the middle-income groups, the existing standards are still applied. After the implementation of different measures, the tax-saving rates of the three groups are more balanced, which can effectively reduce the unfairness of individual income taxdeferred commercial pension insurance. In addition, the implementation effect of the policy depends on the incentive effect produced by the tax-saving effect, and the tax-saving rate can also be used to measure the incentive effect of the policy on individuals. Therefore, under the optimization scheme, it not only realizes the relative fairness of tax preference but also makes the policy achieve nearly the same incentive effect on all income levels.

In order to further compare the degree of tax preference between the new and old schemes, this paper selects two parameters of predetermined interest rate and retirement age for calculation and analysis. For policyholders, the implementation of the retirement age policy is conducive to improving difference of the tax preference; the increase of the predetermined interest rate has more advantages for high-income groups, and for low-income groups, the state needs to introduce corresponding policies to provide more subsidies and support.

\section{Data Availability}

The data used to support the findings of this study are available from the corresponding author upon request.

\section{Conflicts of Interest}

The authors declare that they have no conflicts of interest.

\section{Acknowledgments}

This research was supported by the Taishan Scholars Program of Shandong Province (no. tsqn20161041), the Shandong Provincial Social Science Project Planning Research Project (no. 19CQXJ08), and the Key Project of National Social Science Foundation of China (no. 21AZD071).

\section{References}

[1] J. Creedy and R. Guest, "Changes in the taxation of private pensions: macroeconomic and welfare effects," Journal of Policy Modeling, vol. 30, no. 5, pp. 693-712, 2008.

[2] J. M. Poterba, "Retirement security in an aging population," The American Economic Review, vol. 104, no. 5, pp. 1-30, 2014.

[3] J. Beshears, J. J. Choi, D. Laibson, and B. C. Madrian, "Does front-loading taxation increase savings? Evidence from Roth 401(k) introductions," Journal of Public Economics, vol. 151, pp. 84-95, 2017.

[4] N. S. Karamcheva and G. Sanzenbacher, "Bridging the gap in pension participation: how much can universal tax-deferred pension coverage hope to achieve," Journal of Pension Economics and Finance, vol. 13, no. 4, pp. 439-459, 2013.

[5] J. Antón, "Distributional implications of tax relief on voluntary private pensions in Spain," Fiscal Studies, vol. 28, no. 2, pp. 171-203, 2007.

[6] M. L. Collins, "Private pensions and the gender distribution of fiscal welfare," Social Policy and Society, vol. 19, no. 3, pp. 500-516, 2020.

[7] D. Joulfaian and D. Richardson, "Who takes advantage of taxdeferred saving programs? Evidence from federal income tax data," National Tax Journal, vol. 54, no. 3, pp. 669-688, 2001.

[8] H. Y. Andersen, "Do Tax incentives for saving in pension accounts cause debt accumulation? Evidence from Danish register data," European Economic Review, vol. 106, pp. 35-53, 2018.

[9] X. M. Peng, H. Y. Liu, and J. Sun, "On the social equity of the individual tax deferred pension insurance," Southwest Finance, vol. 11, pp. 36-39, 2014.

[10] W. Q. Zhu and R. C. Tao, "Fairness analysis of China's personal income tax," Review of Economy and Management, vol. 31, no. 6, pp. 89-98, 2015.

[11] W. Huang and B. L. Wang, "The security level of income-taxdeferred enterprise annuity," Journal of Financial Research, vol. 1, pp. 138-155, 2018.

[12] Y. Ji, X. Jin, Z. Xu, and S. Qu, “A mixed 0-1 programming approach for multiple attribute strategic weight manipulation based on uncertainty theory," Journal of Intelligent and Fuzzy Systems, vol. 41, no. 6, pp. 6739-6754, 2021. 
[13] Y. Ji, H. Li, and H. Zhang, "Risk-averse two-stage stochastic minimum cost consensus models with asymmetric adjustment cost," Group Decision and Negotiation, 2021.

[14] Z. M. Yuan and J. L. Guo, "Comparison of tax preference models of private pension plan and its international experience," Taxation and Economy, vol. 6, pp. 80-89, 2018.

[15] K. Fan, W. N. Yang, L. Y. Qian, and Y. X. He, "The classification and calculation of tax rates on tax deferral commercial pension insurance in China," Journal of East China Normal University, vol. 51, no. 4, pp. 133-142, 2019. 